\title{
O Figurino como Instrumento Político: a importância da arte questionadora ${ }^{1}$
}

\author{
Mariana Carvalho Xavier \\ Centro Universitário Belas Artes de São Paulo, São Paulo/SP, Brasil \\ E-mail: marianacxav@gmail.com \\ Rosane Muniz \\ Centro Universitário Belas Artes de São Paulo, São Paulo/SP, Brasil \\ Universidade Federal do Rio Grande do Sul - UFRGS, Porto Alegre/RS, Brasil \\ Centro Universitário Senac de Sãp Paulo, São Paulo/SP, Brasil \\ E-mail: romuniz@gmail.com
}

Resumo

Os movimentos políticos, econômicos e sociais que ocorrem em cada país e ao redor do mundo podem ser temas e/ou influências na concepção da linguagem de uma obra artística. Este artigo objetiva compreender um dos elementos da cena, o figurino, enquanto um instrumento político, um manifesto, investigando se é possível manifestar estas influências criadoras também em uma autoria dos trajes elaborados para uma performance, de forma a compor a dramaturgia. Três trajes de cena, em três contextos políticos diferentes, são analisados neste estudo: da violência política mexicana à polarização do Brasil durante as eleições de 2018, passando pela crise dos refugiados que marcou e marca a história mundial.

Palavras-chave

Figurino. Política. Performance. Cultura. Manifesto.
The political, economic and social movements that occur in each country and around the world can be themes and/or influences on the language conception of an artistic work. This article aims to understand one of the elements of the scene, the costume, as a political instrument, a manifesto, investigating whether it is possible to manifest these creative influences also in an authorship of the costumes designed for a performance, in order to compose the dramaturgy. Three stage costumes, in three different political contexts, are analyzed in this study: from Mexican political violence to the polarization of Brazil during the 2018 elections, going through the refugee crisis that marked and marks world history.

Costume Design. Politics. Performance. Culture. Manifest. 
Neste artigo, o figurino é apresentado como narrativa, levando em consideração as motivações sociais, políticas e econômicas que movimentam a encenação. Com enfoque na criação de trajes de cena que tenham levado em consideração manifestações artísticas e culturais, abordamos os fatores que levaram à cada criação, para compreender se estes estão materializados, de alguma forma.

A arte tem um grande papel na mudança do cenário de um país. Questionamentos levantados por ela causam um grande impacto, em um contexto em que a imaginação efetivamente toma o poder, no qual a transgressão e a criação caminham juntas, com o desejo de mudar um sistema, contestá-lo e fazer a diferença. Como revela Fernanda Maia, diretora musical no Núcleo Experimental de Teatro, em uma das crônicas que vem escrevendo em sua página pessoal na rede social do Facebook: "Arte dói, liberdade dá trabalho, consciência é um incômodo constante, pensamento nos deixa em crise, democracia precisa ser cuidada." (MAIA, 2020. Documento eletrônico).

O figurino pode ser visto como um instrumento político, se tornando consequentemente um manifesto. Os três estudos de caso abordados nesta pesquisa possuem esta característica. Por esta razão, foi necessário investigar as motivações, ideologias e o contexto pertinente à cada criação. $O$ foco está na seguinte questão: A forma como cada artista, na criação de trajes de cena, decide mostrar suas vivências pode gerar um impacto social, contextualizando o aspecto político da dramaturgia?

Para realizar este estudo de caso, foram identificados e analisados três figurinos que tiveram algum tipo de manifestação social como motivação. Desta forma, com o intuito de perceber se o figurino pode ser um instrumento questionador, a pesquisa aborda desde os artistas que os criaram até o contexto político no qual estavam

\footnotetext{
1 Artigo proveniente da pesquisa realizada para o TrabaIho de Conclusão do curso de Pós-Graduação em Cenografia e Figurino do Centro Universitário Belas Artes de São Paulo, aprovado em banca (jun. 2020). Orientadora: Profa. Dra. Rosane Muniz Rocha.
}

inseridos, abrangendo também as técnicas escoIhidas e as ideologias que formaram cada projeto.

A pesquisa tomou como estudo de base três projetos. O primeiro deles mostra o figurino criado pela artista mexicana Eloise Kazan para a personagem Queen Tamora (Rainha Tamora), em um contexto de extrema violência política e social. O segundo projeto envolve uma performance organizada por duas artistas, Charlotte Østergaard e Sally E. Dean - dinamarquesa e com cidadania americana/britânica respectivamente - na qual é abordada a situação dos refugiados e o sentimento que lhes é causado com a situação em que vivem.

Por fim, o terceiro projeto foi criado no Brasil, por uma equipe da Universidade Federal do Rio de Janeiro (UFRJ), proposto pela professora e figurinista Desirée Bastos, e seus alunos Igor Avelino e Rafael Torres. A performance estabelece um paralelo entre a peça Ubu Rei, de Alfred Jarry, e o governo atual, exaltando as semelhanças tirânicas e as injustiças sofridas pela população.

\section{A violência no vestir}

O primeiro estudo de caso é sobre o projeto criado pela figurinista Eloise Kazan para a personagem Queen Tamora no projeto The Titus Procession, que foi criado na cidade do México, em 2007, com base na tragédia Titus Andronicus, de William Shakespeare.

\subsection{Contexto Político}

No contexto político daquele momento, no México, se destaca o segundo mandato do Partido Ação Nacional (PAN) que, após muitas tentativas, conseguiu retirar o partido que estava vigente há mais de 70 anos do poder, o Partido Revolucionário Institucional (PRI), dominado pela elite governante.

$O$ século $X X$ foi marcado por inúmeras insatisfações sociais geradas pelas decisões do PRI, que envolviam privatizações, liberações do comércio e corte dos gastos públicos. As eleições "simulavam" uma democracia, no entanto o contexto em que 
viviam era de fraude, violência e repressão, como dito pelo jornalista, escritor e político peruano Mario Vargas Llosa (2018): "Uma ditatura perfeita".

O PAN, por sua vez, assumiu o poder com a promessa de ser um partido de direita ligado à igreja católica, e o principal opositor do PRI, com um mandato que teve seu início na virada do século XXI e permaneceu por 12 anos. Segundo o cientista político Emerson Cervi, em sua coluna para o Latin America Business Stories (LABS):

A política mexicana foi dominada pelo $P R I$ durante sete décadas no século $X X$, graças a um sistema de representação política fechada e com barreiras para fortalecimento de forças alternativas institucionalizadas. [...] O PAN colocou-se como seu maior opositor durante todo o período. (CERVI, 2018. Documento eletrônico).

As disputas políticas no México tiveram um grande papel no aumento da violência no país, especialmente pela corrupção e intolerância do PRI em seu mandato. Esta relação entre governo e violência fica clara no trecho da jornalista e autora mexicana Anabel Hernández": "Sem uma estratégia do governo para proteger os cidadãos e com uma sociedade mexicana anestesiada, as fronteiras do crime organizado desapareceram, e a violência se transformou em terrorismo." (HERNÁNDEZ, 2019. Documento eletrônico).

Em uma sociedade marcada há gerações pela corrupção e pelo tráfico é difícil estabelecer um plano de mudança, visto que de certa forma a população se habituou ao cenário em que estava inserida. Segundo Hernández (2019), o grande responsável por isto foi a cumplicidade e a inação das autoridades, expandindo os limites da violência e fazendo com que viver com medo fosse normalizado.

2 A jornalista e autora Anabel Hernández escreve há anos sobre cartéis de drogas e corrupção no México. Após ameaças de morte, teve que deixar o país, e vive na Europa desde então. Por seu trabalho, recebeu o Prêmio Liberdade de Expressão da DW em 2019, durante o Global Media Forum, em Bonn.
A respeito do histórico de violência mexicano, as organizações criminosas mantiveram-se na obscuridade durante muitos anos, entretanto, com a virada do século, seu aparecimento em espaços públicos aumentou. Isso se deve, dentre muitos fatores, ao rompimento de acordos relacionados à exclusividade territorial e ao aumento da cumplicidade entre as organizações com os governantes, a polícia e o poder judiciário.

De acordo com o artigo publicado por Víctor Manuel Durand Ponte, pesquisador emérito do Instituto de Pesquisas Sociais da Universidade Autônoma do México (UNAM), a violência no país e os acordos ilegais que eram feitos ameaçavam a autonomia do estado:

As disputas entre os cartéis envolviam funcionários do governo, dividindo-os e enfrentando-os. No final do século passado e nos primeiros anos do atual, a presença e a atividade do narcotráfico e das organizações criminosas tornou-se inaceitável para o governo federal. (PONTE, 2010, p. 138).

Assim, o governo do presidente Felipe Calderón do PAN, de dezembro de 2006 até novembro de 2012, foi marcado pela declaração de guerra ao crime organizado, tornando maior a violência entre os cartéis e destes com as forças do Estado. As consequências deste ato foram graves e deixaram marcas na sociedade, como visto neste outro trecho de Ponte:

A partir dessa decisão, iniciou-se um círculo perverso envolvendo ataques mais intensos do governo contra os cartéis, com confiscos de drogas e com líderes de alto e médio escalão sendo afetados e mortos, gerando intensificação da violência, maior divisão dos cartéis, expansão territorial, mais investidas por parte do governo etc. (PONTE, 2010, p.138).

\subsection{Eloise Kazan}

Eloise Kazan é produtora, figurinista, cenógrafa e diretora de arte. Nasceu no México em 1975, onde estudou Artes Plásticas. Mudou-se para o Reino Unido para cursar pós-graduação em Design. Trabalhou em mais de 60 produções inter-

Xavier, Muniz // O Figurino como Instrumento Político: a importância da arte questionadora

Revista Cena, Porto Alegre, $n^{\circ} 31$, p. 65-76 mai./ago. 2020

Disponível em: http://seer.ufrgs.br/cena 
nacionais para teatro, ópera, dança e cinema. $\mathrm{Na}$ Quadrienal de Praga $2007^{3}$ (PQ 2007), Kazan foi uma das figurinistas com trabalhos expostos na Mostra Nacional do México, que recebeu o prêmio de Medalha de Ouro de Melhor Figurino Teatral.

$\mathrm{Na}$ edição seguinte do mesmo evento, ela exibiu o traje da personagem Queen Tamora, na exposição Figurinos Radicais ${ }^{4}$. Na PQ 2015, Kazan fez parte do corpo de jurados e, na PQ 2019, ministrou palestras e participou de debates. É uma figurinista de grande destaque internacional.

\subsection{Queen Tamora}

O figurino analisado nesta pesquisa foi vestido pela Queen Tamora, personagem criada para a performance The Titus Procession, baseada na tragédia Titus Andronicus, de William Shakespeare. A intenção da figurinista era de criar "uma performance baseada no figurino, em que ele fosse capaz de contar uma história estruturada, sem palavras, usando os figurinos como a maior ferramenta narrativa." (KAZAN, 2011. Documento eletrônico).

Com relação à história da personagem, Tamora se casou com o imperador para se proteger contra Tito e vingar o assassinato de seu filho. E, neste contexto, o casamento obteve um significado diferente do padrão: era um ato de violência, ódio, vingança e perversão do amor. Este texto de Shakespeare é conhecido como o mais violento e sanguinário já escrito pelo autor. Segundo Kazan (2011), nesta concepção:

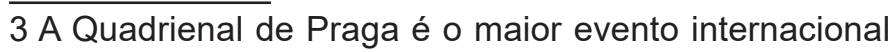
sobre a cenografia, arquitetura e todos os elementos que compõem uma performance teatral. Acontece na capital da República Tcheca desde 1967, tendo surgido a partir de acordo com a Bienal Internacional das Artes Plásticas do Teatro, que acontecia bienalmente na cidade de São Paulo, como evento parte da Bienal de São Paulo, desde 1957.

4 Figurinos Radicais (Extreme Costume) foi uma exposição de trajes que aconteceu como parte da Quadrienal de Praga 2011, na Galeria Nacional de Praga, com trajes criados a partir de materiais alternativos, criada pela figurinista tcheca Simona Rybáková. Foram 20 trajes selecionados ao redor do mundo, sendo o da Queen Tamora um deles, assim como quatro figurinos de artistas brasileiros, em etapa com curadoria de Rosane Muniz
A história de Titus Andrônico é contada pela perspectiva da muda Lavinia, que não tinha língua. Havia figurinos para os personagens, mas também criei trajes representando o espaço, o lugar e eventos passados. [...] Ainda é um "work in progress", ou melhor, uma transformação, mas os primeiros fragmentos de A Possessão de Titus, incluindo este vestido, foram apresentados em uma Mostra de performances para Jovens Artistas, organizada pelo Fundo Nacional Mexicano para as Artes e Cultura (FONCA) (KAZAN, 2011. Tradução nossa. Documento eletrônico).

Kazan tinha como objetivo explorar ao extremo as metáforas do texto e os materiais que utilizaria na construção do traje. O figurino da Queen Tamora representa então uma fortaleza autodestrutiva (figura 1), com uma casca fria e pesada, misturando a pele com a armadura. Ao analisarmos a história política do México, repleta de violência e caos, faz sentido que Kazan tenha criado um figurino como este para a personagem: com mais de duas mil balas de revólver, cedidas como cortesia pelo Exército Mexicano.

Figura 1 - Queen Tamora com seu vestido de noiva, criado pela figurinista Eloise Kazan.

Atriz: Adriana Oliveira. Maquiagem: Maripaz Robles.

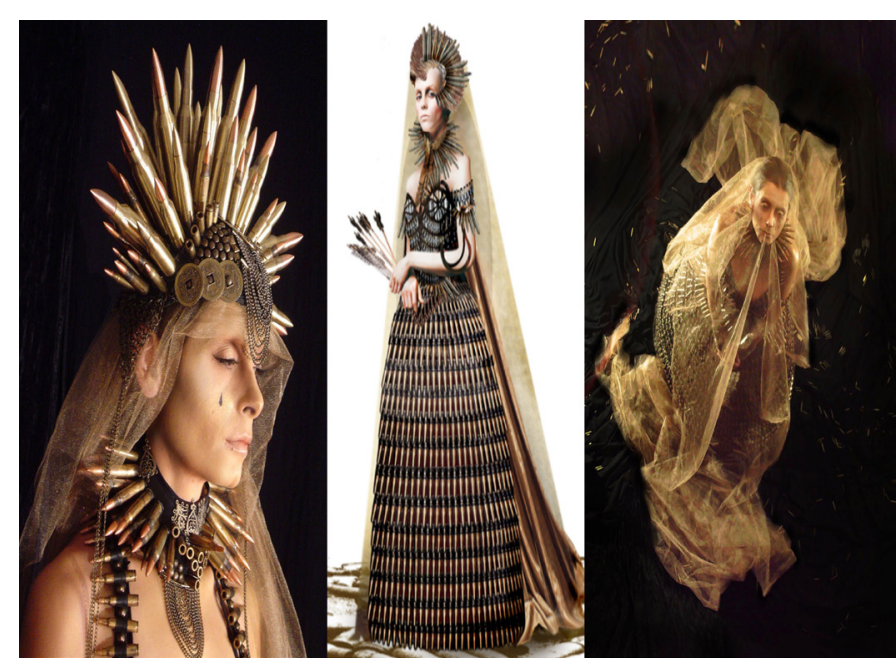

Fonte: Eloise Kazan (2011). 


\section{O refúgio na arte}

O segundo traje a ser analisado pertence a uma performance intitulada Traces of Tissues (Vestígios de Tecido), criada pela artista visual Charlotte Østergaard em conjunto com a artista interdisciplinar Sally E. Dean, que reflete sobre a situação atual dos refugiados. "Como lembramos daqueles que não têm escolha ou lugar para onde ir?" é a pergunta que move este experimento.

\subsection{Contexto Político}

A ideia da performance surge em 2017, em um contexto político marcado pela crise dos refugiados que, segundo consta no site do Alto Comissariado das Nações Unidas para Refugiados (ACNUR), são definidos como:

[...] pessoas que estão fora de seu país de origem devido a fundados temores de perseguição relacionados a questões de raça, religião, nacionalidade, pertencimento a um determinado grupo social ou opinião política, como também devido à grave e generalizada violação de direitos humanos e conflitos armados. (ACNUR, Ano desconhecido. Documento eletrônico).

O número estimado de pessoas forçadas a se deslocar no mundo, ainda segundo a ACNUR, em junho de 2019, gira em torno de 70,8 milhões. Cerca de $80 \%$ dos refugiados vivem em países vizinhos de seu país de origem, sendo a maioria da Síria, Afeganistão e Sudão do Sul. Os países que mais abrigam refugiados são Turquia, Paquistão, Uganda, Sudão e Alemanha, respectivamente.

Dentre as pessoas forçadas a se deslocar ao redor do mundo, 41,3 milhões são deslocados internos (pelo mesmo motivo de um refugiado, mas se mantém no mesmo país), 25,9 milhões são de refugiados e 3,5 milhões de solicitantes de refúgio (os que ainda não tiveram seu pedido devidamente avaliado pelos sistemas nacionais de proteção e refúgio).

Segundo a Organização das Nações Unidas
(ONU), quando as pessoas são deslocadas à força, para proteger a vida e a integridade física, elas têm duas opções: a morte por privação, assaltos ou genocídios; ou a vida no exílio. Os motivos mais comuns para que uma pessoa precise de refúgio são catástrofes naturais, guerras e conflitos políticos.

Uma questão recorrente nos assuntos relacionados aos refugiados é a falta de empatia e de auxílio de alguns países, estes que fecham fronteiras com arame farpado para não recebê-los, mesmo em meio a uma situação caótica. A situação se assemelha a de criminosos e traidores, como se tivessem sido expulsos de seus países, e não obrigados a sair por questões de sobrevivência. O tratamento dos refugiados nos dias de hoje fica explícito no trecho do sociólogo e filósofo Zygmunt Bauman:

Crianças afogadas, muros apressadamente erguidos, cercas de arame farpado, campos de concentração superlotados [...] todas essas ofensas morais cada vez são menos notícia e aparecem com menor frequência no noticiário. Infelizmente, o destino dos choques é transformar-se na rotina tediosa da normalidade - e dos pânicos é desgastar-se e desaparecer da vista e das consciências, envoltos no véu do esquecimento. (BAUMAN, 2017, p. 8).

\subsection{Charlotte Østergaard e Sally E. Dean}

Charlotte Østergaard é uma artista visual dinamarquesa que realiza trabalhos com criação de figurinos, moda e objetos têxteis. Tem paixão pelas técnicas de dobraduras, em que transforma um material unidimensional em formas móveis tridimensionais, objetos ou vestimentas, alterando a superfície e estrutura dos têxteis. Nos últimos 23 anos trabalha tornando o corpo como um meio de expressão cultural e artística, usando-o como ferramenta para criar suas performances. Também desenhou figurinos para mais de 50 apresentações de dança contemporânea, tendo recebido diversos prêmios de teatro.

Sally E. Dean é uma artista interdisciplinar com ascendência americana e britânica, criadora de performances e professora há mais de 20 anos - em se- 
tores universitários, profissionais e comunitários na Europa, Ásia e Estados Unidos da América. É responsável por liderar o projeto "Somatic Movement, Costume \& Performance Project”, desde 2011, no qual projeta figurinos que despertam consciência psicofísica.

As duas artistas se juntaram em 2017 e iniciaram um projeto chamado BETWIXT, em que a dupla realiza uma colaboração interdisciplinar internacional, visando criar uma obra de arte total ${ }^{5}$ - na qual o figurino e o material utilizado criam juntos um movimento próprio, questionando sempre a relação corpo/material/traje.

\subsection{Traces Of Tissues}

O projeto Traces Of Tissues foi apresentado na Quadrienal de Praga em 2019, como parte do Festival de performances em site-specific $^{6}$. É possível compreender o sentido que esta performance possui por meio do trecho escrito pelas artistas Østergaard e Dean (2018):

Traces of Tissues é um lugar específico para aqueles que vivem no espaço liminar - um local no meio. Entrelaçando o figurino, a coreografia somática e o local físico, essa performance homenageia a situação atual do refugiado. Traces of Tissues questiona: "Como lembramos daqueles que não têm escolha ou lugar para onde ir?". (ØSTERGAARD; DEAN, 2018. Tradução nossa. Documento eletrônico).

De acordo com Østergaard 7 , o ponto de partida para a criação do figurino surgiu durante sua pesquisa para um projeto artístico realizado na escola dinamarquesa Danish National School of Performing Arts. Nele, ela se aprofundou na forte relação estabelecida

5 Obra de arte total - conceito do compositor alemão Richard Wagner, referente a conjugação de música, teatro, canto, dança e artes plásticas em uma única obra de arte.

6 Site-specific é um nome dado às obras que configuram uma situação espacial especifica, levando em conta as características do local, e que não podem ser apreendidas senão ali.

7 Informação fornecida por Charlotte Østergaard, em entrevista por e-mail, em 15 abr. 2020. entre os figurinistas e os performers, criando figurinos que os conectassem. Estes trajes foram levados para uma residência realizada em conjunto com Dean, em Londres, onde foram explorados e aperfeiçoados.

A estrutura arquitetônica de onde parte a performance consiste nos artistas presos à pilares cinzentos, altos e afiados, como em um ambiente industrial. Os performers se movimentam, realizando uma coreografia, mas presos por tiras de tecidos. A luta de fronteiras envolvendo corpos, trajes e lugares formam uma estética entre o trágico e o cômico, uma dança que se desenrola em fragilidade, poder e esperança. (ØSTERGAARD; DEAN, 2018).

De acordo com o texto escrito pela figurinista e professora americana Sabrina Notarfrancisco, para o jornal Theatre Design \& Technology (2019), a metáfora dos artistas se afastando dos pilares representa o fato dos refugiados se distanciarem fisicamente dos seus lares enquanto permanecem firmemente presos ao passado. A relação da criação do figurino com o tema dos refugiados fica exemplificada no seguinte trecho de Notarfrancisco:

As fitas vermelhas e a cor da pele eram viscerais [...]. Quando combinadas com o movimento e o trabalho de voz dos performers, as fitas efetivamente transmitiram o trauma profundo, tanto físico quanto emocional de ser deslocado. A ação dinâmica das fitas esticando até o seu limite criaram um visual de tensão que falava muito sobre a difícil situação dos refugiados. (NOTARFRANCISCO, 2019, p. 39. Tradução nossa).

Segundo Østergaard e Dean (2019, p.17), para Blue Pages - jornal elaborado pela Sociedade Britânica de Designers do Teatro - atualmente existem 68,5 milhões de pessoas que foram forçadas a se deslocar pelo mundo em busca de um novo lugar para ficar, após perderem ou serem expulsas de seus lares.

Apresentar a performance Traces of Tissues na Quadrienal de Praga (figura 2) tem um peso maior do que o aparente à primeira vista, já que foi o local onde 45.408 judeus foram mantidos antes de serem enviados para campos de a importância da arte questionadora

Revista Cena, Porto Alegre, $n^{\circ} 31$, p. 65-76 mai./ago. 2020

Disponível em: http://seer.ufrgs.br/cena 
concentração - situação atual dos refugiados.

A intenção de Østergaard e Dean ao criarem esta performance era a de que os trajes fossem como os corpos expostos, tecidos de dentro para fora, revelando traços de tecidos internos. Com relação à coreografia, o ponto de partida foi estudar o que acontece quando um grupo está em pânico ou sob ataque - eles se juntam ou se separam?

O impacto que ambas queriam gerar fica explícito no trecho final da entrevista concedida por Østergaard8: "O impacto corporal de estar preso. Uma expressão visual de ser exposto, não nu, mas exposto, a pele sensível contra o local industrial".

Figura 2 - Performance Traces os Tissues, realizada durante a Quadrienal de Praga 2019.

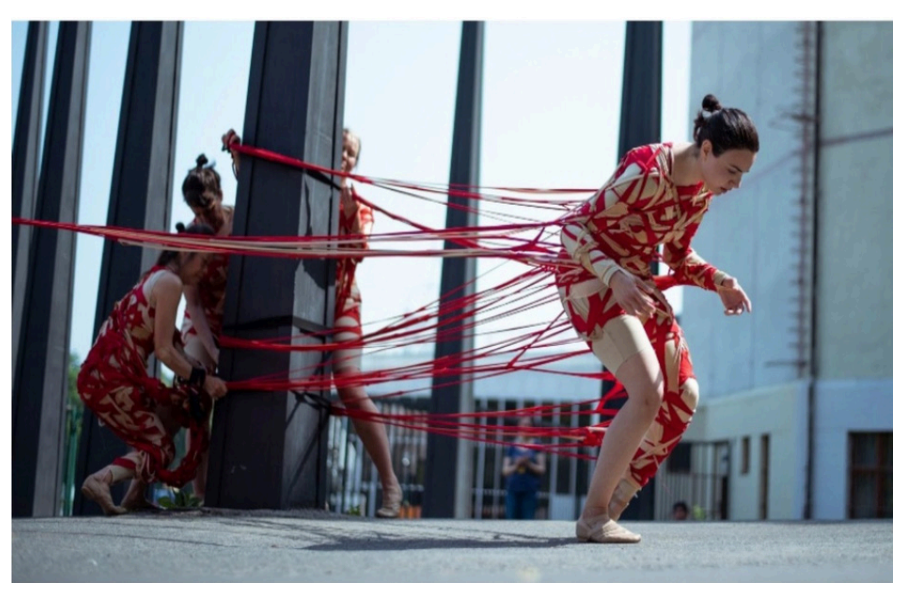

Fonte: Quadrienal de Praga 2019.

\section{A tirania no poder}

O traje final a ser analisado nesta pesquisa pertence a uma performance baseada na peça Ubu Rei, de Alfred Jarry, criada pela professora Desirée Bastos, junto com seus alunos Igor Avelino e Rafael Torres. Durante a pesquisa do trio foi levantada a semelhança entre a obra original e o contexto político do Brasil, em um cenário às vésperas de eleições à presidência, marcado pela vitória de Jair Messias Bolsonaro.

8 Informação fornecida por Charlotte Østergaard, em entrevista por e-mail, em 15 abr. 2020.

\subsection{Contexto político}

A candidatura de Bolsonaro, em 2018, foi articulada em um Brasil enfraquecido pela corrupção e pelas constantes crises econômicas, ambas características de anos de conflitos e trocas de poder entre os partidos políticos de direita e esquerda. Estes conflitos de ideologias acompanham o Brasil desde antes da ditadura militar - iniciada em abril de 1964 - mas, neste artigo, para compreensão do contexto político vigente na criação da performance serão analisados acontecimentos iniciados na virada do século $X X$.

A década de 1990 terminou com o mandato duplo de Fernando Henrique Cardoso (FHC, Ano desconhecido), de janeiro de 1995 até janeiro de 2003, eleito democraticamente pelo Partido da Social Democracia Brasileira (PSDB). Seguido por Luiz Inácio Lula da Silva, também eleito e reeleito democraticamente, governando até janeiro de 2011, pelo Partido dos Trabalhadores (PT), sendo o primeiro presidente da República de origem operária.

O governo de Lula teve seu início marcado pela política da distribuição de renda, possibilitando uma estabilidade econômica em relação ao período anterior, como é exemplificado no trecho escrito pelo doutorando e mestre em história Tales Pinto para o site Brasil Escola:

A distribuição de renda ocorreu através de políticas como Bolsa Família, que além de uma renda mínima, garantiu a obrigatoriedade de um nível educacional mínimo à quase toda a população em idade escolar [...] e o estímulo econômico a regiões extremamente pobres do território nacional. (PINTO, Ano desconhecido. Documento eletrônico).

Em oito anos, sua administração tirou milhares de pessoas da pobreza absoluta. No entanto, foi marcada pelos escândalos de casos grandes de corrupção, como o mensalão - que supostamente já existia desde a era FHC. Este que, segundo a mestre em história Juliana Bezerra (2019), era um sistema de pagamentos ilícitos que o governo federal usava para garantir o apoio dos deputados e senadores nas

Xavier, Muniz // O Figurino como Instrumento Político: a importância da arte questionadora

Revista Cena, Porto Alegre, $n^{\circ} 31$, p. 65-76 mai./ago. 2020

Disponível em: http://seer.ufrgs.br/cena 
votações de leis e emendas favoráveis ao governo.

O PT, após o fim do período de mandato do Lula, lançou a candidata Dilma Rousseff ao governo, que foi eleita e governou de janeiro de 2011 até agosto de 2016 - quando sofreu um impeachment. Nos primeiros anos sua aceitação foi alta, mantendo as promessas de seu antecessor em relação a uma "nova matriz econômica", baseada em desoneração de impostos, concessão em massa de crédito público, juros artificialmente baixos e crescimento por meio do consumo.

Entretanto, as medidas tomadas não geraram os resultados esperados, fazendo com que a popularidade de Dilma diminuísse aos poucos. "Em 2014, após as eleições, ela não explicou à população por que teve que recuar de suas promessas de campanha. Simplesmente começou a fazer um ajuste, sem admitir erros", comentou o cientista político Rolf Rauschenbach (2016. Documento eletrônico), da Universidade de St. Gallen.

O processo de impeachment polarizou ainda mais o Brasil. O documentário Democracia em Vertigem (2019), de Petra Costa, que contempla o período do otimismo do lulismo à incredulidade diante da eleição de Bolsonaro, em 2019, explicita bastante o que aconteceu no Brasil neste período. Nele, também é abordada a prisão do ex-presidente Lula, em abril de 2018, e o consequente impedimento de sua candidatura à Presidência, seguido por momentos em que o Brasil muda totalmente seu rumo e elege um presidente com características totalitárias e conservadoras, do Partido Social Liberal (PSL).

As diferenças do impacto que estes dois presidentes geraram em suas respectivas eleições, juntamente com a polarização de suas ideologias, ficam explícitas no trecho da jornalista, escritora e documentarista Eliane Brum em seu livro "Brasil, construtor de ruínas - Um olhar sobre o país de Lula a Bolsonaro":

Lula foi exceção. E Bolsonaro é exceção. Nenhum deles pertence a nenhuma elite. Ambos, porém, são opostos. Não apenas por um ser de centro-esquerda e o outro de extrema-direita. Mas porque Bolsonaro rompe com a ideia da excepcionalidade. Em vez de votar naquele que reconhecem como deten- tor de qualidades superiores, que o tornariam apto a governar, como aconteceu com Lula, quase 58 milhões de brasileiros escolheram um homem parecido com seu tio ou primo. Ou consigo mesmos. (BRUM, 2019, p. 183).

As eleições de 2018 deixaram ainda mais clara a divisão vermelha versus verde e amarelo - visto que a primeira representa a cor do Partido dos Trabalhadores, enquanto a segunda mostra as cores da bandeira Brasileira, apropriada nestes últimos anos pelos partidos conservadores. Uma parcela da população acreditava na volta do PT ao poder por meio do candidato acadêmico, advogado e político Fernando Haddad; e outra parcela acreditava que o capitão reformado do exército Jair Bolsonaro poderia trazer mudanças e combater a corrupção, mesmo com o fato dele ter sido deputado federal por sete mandatos sem grandes feitos, e de ter sido caracterizado como totalitário e conservador.

O resultado das eleições foi obtido graças à muitos fatores, e foi considerado por grande parte da população como uma forma de esperança, devido a situação crítica em que o país estava, como mostrado no trecho de Brum:

Em 2017, o ano da fabricação de monstros, o presente e o futuro estavam claramente ameaçados no Brasil, porque havia menos dinheiro para saúde e educação, porque a Amazônia estava sendo destruída e porque direitos profundamente ligados à existência humana estavam sendo exterminados por um Congresso formado em grande parte por corruptos. [...] Com o ódio canalizado contra falsos mortos, os homens que pregam e praticam monstruosidades aumentam suas chances de serem eleitos. (BRUM, 2019, p; 183).

A performance desenvolvida pelo grupo da UFRJ surgiu neste contexto: de muitas manifestações de ambos os lados até que os resultados definiram Bolsonaro como presidente no segundo turno. As eleições foram conturbadas, com disseminação constante de notícias falsas (Fake News), em conjunto com discursos de ódio. E a gravidade das marcas que o período presidena importância da arte questionadora

Revista Cena, Porto Alegre, $n^{\circ} 31$, p. 65-76 mai./ago. 2020

Disponível em: http://seer.ufrgs.br/cena 
cial de Bolsonaro vai deixar nos brasileiros são mostradas no trecho da jornalista Helena Chagas:

[...] do ponto de vista histórico, essa tentativa diária de corrosão dos valores que forjaram a democracia em que vivemos hoje, e que permitiu sua eleição, seja o maior dano do governo do capitão ao Brasil. Pior até do que a inépcia e a incapacidade de governar e resolver problemas como o desemprego e a estagnação econômica. (CHAGAS, 2019. Documento eletrônico).

\subsection{Desirée Bastos, Igor Avelino e Rafael Torres}

Desirée Bastos ${ }^{9}$ é cenógrafa, figurinista e diretora de arte, também atua como professora efetiva da Escola de Belas Artes (EBA), no curso de Artes Cênicas da Universidade Federal do Rio de Janeiro (UFRJ) desde 2010, onde teve como alunos Igor Avelino e Rafael Torres. Tem experiência atuando nas diversas linguagens artísticas, como teatro, performance, carnaval, ópera e dança. Bastos já teve trabalhos expostos em mostras competitivas como a Quadrienal de Praga e o World Stage Design, assim como indicações aos prêmios Zilka Sallaberry e FITA.

Igor Avelino e Rafael Torres são graduandos bacharéis em Artes Cênicas com habilitação em Indumentária na EBA da UFRJ. Avelino realizou outros projetos na faculdade juntamente com o curso de Direção Teatral da UFRJ na "Mostra Mais 2018", sendo responsável pelo figurino da peça Revolução na América do Sul, de Augusto Boal. Torres é bolsista do Programa de Bolsas de Iniciação Artística e Cul-

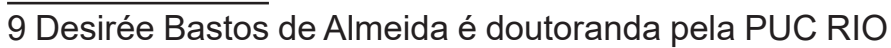
em Design, possui especialização em Design pelo Instituto Politécnico de Milão (2018), mestrado no Programa de Pós-Graduação em Artes Visuais pela Universidade Federal do Rio de Janeiro (2010), graduação em Artes Cênicas com habilitação em Cenografia, pela Universidade Federal do Rio de Janeiro (2003) e graduação em Artes Cênicas com habilitação em Indumentária pela Universidade Federal do Rio de Janeiro (2002).

Ver mais em: < http://lattes.cnpq.br/9034891615462990 >. Acesso em: 10 abr. 2020. tural na linha de pesquisa "Formas Particulares de Design". Atualmente se dedica a essa pesquisa na área de Design e desenvolve seu Projeto de Graduação (TCC). Ambos possuem experiência na área do figurino, com ênfase em confecção dos trajes e seus beneficiamentos têxteis, atuando nas linguagens artísticas: teatro, carnaval, ópera e performance.

\subsection{Ubu Rei}

Ubu Rei foi o único projeto latino-americano apresentado na mostra Common Design Project, que fazia parte da sessão $P Q$ Studio na Quadrienal de Praga 2019. Esta mostra consistia em criar uma performance que contemplasse cenografia, figurinos, iluminação, design de som e direção baseados na peça Ubu Rei, de Alfred Jarry.

A professora Desirée Bastos é a responsável por ministrar uma disciplina chamada Tópicos Especiais em Performance, na qual explora as técnicas artesanais de malharia (tricô e crochê) para criar estruturas que, segundo ela ${ }^{10}$, serviriam tanto para vestir o corpo quanto vestir o espaço. Assim, foi na sala de aula que iniciou o estudo de materiais para o projeto, junto com os alunos Igor Avelino e Rafael Torres.

A equipe decidiu por traçar um paralelo com o contexto político da época, as eleições presidenciais de 2018, e relacioná-lo diretamente com a obra de Jarry, mostrando a semelhança na disputa de poder e nas formas tirânicas de governar. A imagem do Pai UBU - que se tornou rei devido à sua bestialidade e violência sem limites - presente na peça, se assemelhava à imagem do candidato a presidência da República na época, Jair Messias Bolsonaro.

Com as relações e os conceitos definidos, iniciou-se uma pesquisa detalhada dos materiais, começando pelas técnicas que seriam utilizadas. $\mathrm{O}$ objetivo era explorar as possibilidades de transformar ideias e conceitos em materiais e objetos. A forma de trabalho fica clara no trecho de Almeida:

10 Informação fornecida por Desirée Bastos, em entrevista por e-mail, em 5 abr. 2020.

Xavier, Muniz // O Figurino como Instrumento Político: a importância da arte questionadora

Revista Cena, Porto Alegre, $n^{\circ} 31$, p. 65-76 mai./ago. 2020

Disponível em: http://seer.ufrgs.br/cena 
Os objetos deveriam ter a capacidade de comunicar apenas através da leitura de sua imagem. Este tipo de percurso - de focar no micro e ir aos poucos expandindo para o macro - é para mim primordial para o alcance de uma polissemia visual. (ALMEIDA, 2020, p. 33).

Com o aprofundamento do estudo da malharia foi possível, com sobreposições de materiais, criar uma teia capaz de formar uma estrutura vestível - um híbrido entre máscara, figurino e instalação. Na técnica utilizada reside toda a efemeridade de uma performance, como dito por Almeida:

O projeto nasce de uma proposta plástica
a partir da poética própria da técnica de
malharia. Ao mesmo tempo que se ins-
taura por laços fortes, pode ser desman-
chada facilmente com um puxar de fios.
[...] Não há uma garantia de permanên-
cia, o que existe é uma eterna relação de
fazer e desfazer. (ALMEIDA, 2020, p. 33).

Com a técnica de malharia definida, o passo seguinte do processo envolveu a escolha dos fios, que precisava ser inovadora e pudesse ser trabalhada para criar relações com as ideias expostas no texto. Torres propôs o uso da ráfia de plástico verde musgo e do saco de lixo preto cortado em tiras - representando os sacos utilizados para cobrir cadáveres - ambos com simbologias fortes e apelo à vilania com o meio ambiente.

Posteriormente surgiu a ideia da fita zebrada, utilizada como isolamento de cenas de crime ou alerta de segurança, assumindo a simbologia do terror implantado por governos autoritários. Com os materiais, a técnica e a estrutura definida, a equipe decidiu criar uma instalação performática. Logo, condensou a história do Ubu Rei na tirania do casal principal, e deixou o espectador substituir os outros personagens, assim fazendo com que tivesse a oportunidade de ser ora tirano, ora tiranizado.

Em maio de 2019, movimentos populares de protesto tiveram início por todo o Brasil, lutando contra os cortes estabelecidos pelo governo de Bolsonaro em relação à educação. Neste contex- to, o projeto foi levado às ruas para experimentar a relação que o público teria com ele, dentro de uma manifestação. As figuras, segundo Almeida, despertaram enorme curiosidade, e a experiência deixou evidente a falta de uma contribuição sonora para ambientar melhor a performance.

Assim, foi criado um dispositivo sonoro que combinava os discursos carregados de ódio proferidos nas últimas eleições por Bolsonaro e, posteriormente, pelo presidente eleito dos Estados Unidos da América - Donald John Trump. Fazendo assim com que o espectador do evento internacional, também pudesse reconhecer e entrar no pensamento dos presidentes em questão, facilitando com que se sentisse como locutor de algumas das terríveis falas.

Figura 3 - Performance Ubu Rei, realizada durante a Quadrienal de Praga 2019.

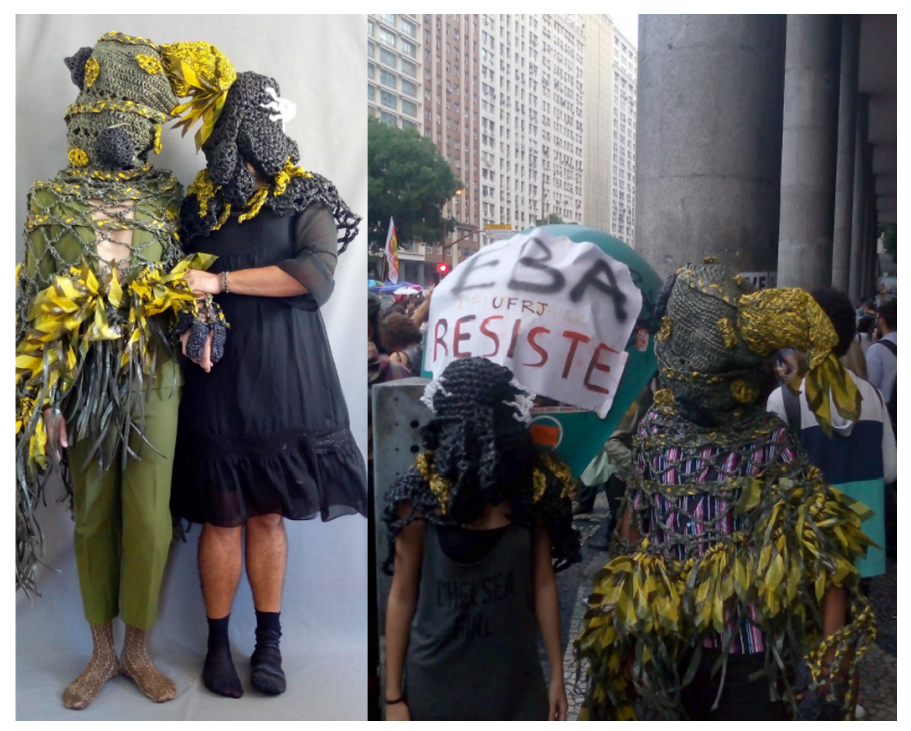

Fonte: Desirée Bastos.

Considerações Finais

A pesquisa iniciou-se com o seguinte questionamento: A forma como cada artista decide mostrar suas vivências gera um impacto social, podendo contextualizar a dramaturgia de forma política por meio dos trajes de cena? E para respondê-lo foi necessário estudar as motivações para a criação dos figurinos, em conjunto com o resulta- 
do obtido e o impacto que geraram na sociedade.

Os seis artistas citados neste artigo foram responsáveis pela criação de três figurinos, estes que mostraram-se instrumentos políticos e revelaram a importância da arte questionadora. A importância do tema aumentou gradativamente ao relacioná-lo com o cenário político de cada país, mostrando que o contexto em que estamos inseridos afeta diretamente a maneira como nos expressamos e realizamos manifestações artísticas.

Cada vez mais é necessário se posicionar, questionar e lutar por mudanças, em uma sociedade em que muitas pessoas se acomodam é necessário ser a diferença. Figurino é arte, moda é arte, e arte tem o papel de inspirar, questionar e até mesmo incomodar, proporcionando diferentes sentimentos - a quem faz e a quem vê.

Os figurinos estudados propuseram questionamentos de grande importância, da violência política à polarização de um país, passando pela crise dos refugiados - que atinge o mundo todo. Ao analisá-los e compreendê-los, ficou extremamente claro que a arte vem em tempos de crise, com a intenção tanto de trazer conforto e pertencimento, quanto de inconformidade e desejo de mudança.

O estudo deste tema proporcionou um sentimento de pertencimento - visto que os artistas usavam sua voz e sua arte para se posicionar, cada história e relatos lidos instauravam ainda mais a sede de lutar por mudanças efetivas hoje. A liberdade dos artistas, em poder expressar isso de forma tão forte e sensível, é uma grande fonte de inspiração. Quanto mais conhecimento se adquire, maior a vontade de conhecer a história por trás de cada manifestação artística e como o contexto político, econômico e social as impactou.

Por fim, fica a certeza de que a forma como estes artistas decidiram demostrar suas vivências, sejam elas devido ao impacto da história dos países em que viveram ou da maneira como escolheram lidar com elas, os faz responsáveis por mudanças, sejam pessoais ou sociais. O que prova a característica autoral e dramatúrgica do artis- ta denominado como figurinista. E a importância da liberdade de expressão para a criação artística.

Referências

ACNUR. Refugiados. Agência da ONU para Refugiados UNHCR/ACNUR.. Disponível em: < https://www. acnur.org/portugues/quem-ajudamos/refugiados/\# > . Acesso em: 10 abr. 2020.

ALMEIDA, Desirée Bastos de. Desirée Bastos deAlmeida. Currículo Lattes. Disponível em: < http://lattes.cnpq. br/9034891615462990 >. Acesso em: 10 abr. 2020.

ALMEIDA, Desirée Bastos de. Ubu Rei: Uma participação latino-americana na PQ19. Revista Cena, Porto Alegre, $n^{\circ} 30$, p. 31-38, jan./abr. 2020. Disponível em: < https://seer.ufrgs.br/cena/article/ view/97064/56471 >. Acesso em: 20 abr. 2020.

BAUMAN, Zygmunt. Estranhos à nossa porta. 1.ed. Rio de Janeiro: Editora Zahar, 2017.

BEZERRA, Juliana. Governo Lula. Toda Matéria, 08 nov. 2019. Disponível em: < https://www.todamateria. com.br/governo-lula/ >. Acesso em: 12 abr. 2020.

BRUM, Eliane. Brasil, construtor de ruínas: Um olhar sobre o país, de Lula a Bolsonaro. 1.ed. Porto Alegre: Editora Arquipélago, 2019.

CERVI, Emerson. Um governo de esquerda em um continente que gira à direita. $L A B S$ : Latin America Business Stories, 13 dez. 2018. Disponível em: < https://labs.ebanx.com/pt-br/artigos/america-latina/ um-governo-de-esquerda-em-um-continente-que-gira-a-direita/ >. Acesso em: 15 mar. 2020.

CHAGAS, Helena. O discurso de ódio e a brutalidade de Bolsonaro. Brasil 247, 29 jul. 2019. Disponível em: < https://www.brasil247.com/blog/o-discurso-do-odio-e-da-brutalidade-de-bolsonaro $>$. Acesso em: 13 abr. 2020. 
DEMOCRACIA em vertigem. Direção de Petra Costa. Produção de Joanna Natasegara e Tiago Pavan. São Paulo: Busca Vida Filmes, 2019.

FHC. Fernando Henrique Cardoso. Disponível em: < https://fundacaofhc.org.br/ruth-e-fhc/fernando-henrique-cardoso >. Acesso em: 12 abr. 2020.

HERNÁNDEZ, Anabel. México, da violência criminosa ao terrorismo. Deutsche Welle, 15 nov. 2019. Disponível em: < https://p.dw.com/p/3Sw80 > . Acesso em: 12 abr. 2020.

KAZAN, Eloise. Titus Andronicus, Extreme Costume Project. Eloise Kazan. Disponível em: < https:// eloisekazan.myportfolio.com/titus-andronicus-extreme-costume-project $>$ e $<$ https://eloisekazan.com/ > . Acesso em: 15 mar. 2020.

LLOSA, Mario Vargas. Começa a cair a ditadura perfeita?. Estadão, 07 dez. 2018. Disponível em: < https://opiniao.estadao.com.br/noticias/geral,comeca-a-cair-a-ditadura-perfeita,70002636249 >. Acesso em: 12 abr. 2020.

MAIA, Fernanda. Facebook, 15 mar. 2020. Disponível em < https://www.facebook.com/fernanda. maia.12576/posts/10219341922516370_. Acesso em: 20 mar. 2020.

NOTARFRANCISCO, Sabrina. Costume Roars Back. Theatre Design \& Technology, $\mathrm{n}^{\circ} 55,4$. ed., Nova lorque: Nxt Book, out. 2019, p. 36-45. Disponível em: < https://www.nxtbook.com/nxtbooks/hickmanbrady/ tdt_2019fall_public/index.php\#/1 >. Acesso em: 10 mar. 2020.

ONU. A ONU e os Refugiados. Nações Unidas Brasil. Disponível em: < https://nacoesunidas.org/acao/ refugiados/ >. Acesso em: 10 abr. 2020.
ØSTERGAARD, Charlotte; DEAN, Sally. Traces of Tissues. Betwix Duo. 2018. Disponível em: < https:// betwixtduo.com/traces-of-tissues/ >. Acesso em: 16 mar. 2020.

ØSTERGAARD, Charlotte; DEAN, Sally. Traces of Tissues at PQ. Blue Pages - A journal for the Society of British Theatre Designers. $n^{\circ} 2$, 18. ed., p. 16-17. Cardiff, 2019.

PINTO, Tales dos Santos. Resumo da História da República Brasileira. Brasil Escola. Disponível em: < https://brasilescola.uol.com.br/historiab/brasil-republica2.htm >. Acesso em: 12 abr. 2020.

PONTE, Víctor Manuel Durand. Notas para entender a realidade mexicana. In: Novos Estudos. CEBRAP, $\mathrm{n}^{\circ}$ 88. Tradução de Luciana Pudenzi. São Paulo: nov. 2010, p. 135-151. Disponível em: < https://doi. org/10.1590/S0101-33002010000300008 >. Acesso em: 15 mar. 2020.

RAUSCHENBACH, Rolf. Os fatores que levaram à queda de Dilma. Deutsche Welle, 31 ago. 2016. Disponível em: < https://www.dw.com/pt-br/ os-fatores-que-levaram-\%C3\%A0-queda-de-dilma/a-19514830 >. Acesso em: 12 abr. 2020.

Recebido: 10/06/2020

Aprovado: 20/07/2020 